\title{
Effect of Carbonation in Mortars with Different Types of Metakaolin and Curing Procedures
}

\author{
Helena Carasek, Mônica E. Jungblut, Paulo M. Passos and Oswaldo Cascudo \\ PPG-GECON, Universidade Federal de Goiás-UFG, Av. Universitária, nº 1488, 74605-220-Goiânia, \\ Brazil, hcarasek@ufg.br; monicaengel.j@hotmail.com; paulompengc@gmail.com and \\ ocascudo@ufg.br
}

\begin{abstract}
This study aimed to evaluate the influence of different types of metakaolin and curing conditions on mortars depth of carbonation. To do so, prismatic mortar specimens were produced by using three different 1:2 mix proportions (binder: sand): a reference mix proportion (without mineral addition) and two mixes with partial replacement of the cement by metakaolin, in the content of $10 \%$ by mass of cement. Two types of metakaolin with different characteristics were used in order to verify their capacity of changing the mortar microstructure and the pore solution, modifying this way the carbonation behavior of these materials. Three curing conditions for the test specimens were defined: no wet curing and wet curing (by immersion in water) for 3, 9 and 28 days. After the accelerated carbonation procedure in a $\mathrm{CO}_{2}$ chamber (in an atmosphere of $10 \%$ of $\mathrm{CO}_{2}$ ), with a relative humidity of $70 \%$ and a temperature of $20^{\circ} \mathrm{C}$, for a period of 7 days, the carbonation depth was measured by using pH-indicators based on phenolphthalein and thymolphthalein. The results indicated influence of the type of curing in the carbonated depth and the significant interaction between curing and the type of metakaolin. When wet curing was not performed, the carbonation was more intense in the reference mortar. The effect of curing in the mortars with metakaolin was much less significant compared to that in the reference mortar. A global discussion about carbonation behavior of metakaolin modified mortars will be performed, based on the characteristics of the metakaolins.
\end{abstract}

Keywords: Carbonation, Durability, Metakaolin, Curing Procedures, Mortar.

\section{Introduction}

The durability of structures fits into an important context for building performance, as well as sustainability and economy.

Among the phenomena responsible for the deterioration of reinforced concrete, there is the reinforcement steel corrosion due to carbonation or chloride attack. This pathological manifestation causes the most damage due to the technical difficulty of long-term recovery and to the cost involved (Castro et al., 2008). Carbonation is a natural phenomenon that occurs by the chemical reaction between carbon dioxide, presents in the atmosphere, with cement hydration products, thus reducing the concrete $\mathrm{pH}$. As a result of the phenomenon, the depassivation of reinforcement steel occurs, facilitating the onset of corrosion.

In this context, mineral additions play an important role in the improvement of concrete and mortars properties, regarding mechanical resistance and durability, since its use in concrete improves the interfacial transition zone, densifies the cement paste, refining pores and reducing their interconnectivity. On the other hand, when considering carbonation, additions can lead to a negative effect, namely: a reduction in the carbonation resistance of the concrete, due to the reduction of the "alkaline reserve" of the cementitious system. This effect is influenced by the type and content of mineral addition used, as well as by the water/binder ratio and curing 
conditions (Cascudo; Carasek, 2011).

Several authors have studied the effect of mineral additions on durability parameters, such as porosity, permeability, carbonation, chloride attack and others (Hossain et al., 2016; Papadakis, 2000; Lim; Mondal, 2015). Some authors report that the replacement of cement by metakaolin increases the carbonation depth (Meddah et al., 2018; Fikhailenko et al., 2018), whereas other researchers have observed smaller depths (Duan et al., 2012, 2013; Rossignolo; Oliveira, 2006). So, there are still divergences in relation to the behavior of concrete or mortar modified with metakaolin, with regard to its performance against carbonation.

Thus, this work aims to analyze the influence of different metakaolins and curing conditions in the accelerated carbonation of mortars, trying to understand this behavior from the point of view of the characteristics of metakaolin. In addition, it was sought to analyze the relationship between the measurements of carbonated depth using two $\mathrm{pH}$ indicators: phenolphthalein and thymolphthalein based solutions.

\section{Experimental}

\subsection{Materials}

The mortars were produced with a washed riverbed quartz sand, with a fineness module of 1.65 and a maximum size of particles of $1.18 \mathrm{~mm}$. The cement used was a Brazilian-type CP II F-40 portland cement, with a specific surface area of $4120 \mathrm{~cm}^{2} / \mathrm{g}$ and chemical characteristics according to Table 1 $\mathrm{g} / \mathrm{cm}^{3}$ and solids conte derived from different mortars. Brazilian-type R (NF EN 197-1: 2012), bein $25 \%$ in mass of limestone fillet according to the
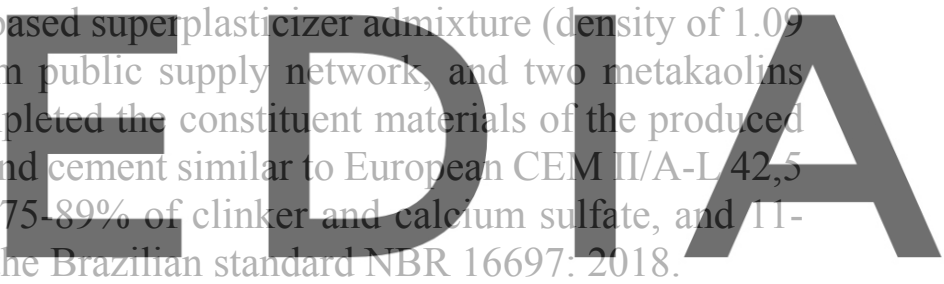

Register for free at https//www.scipedia.com to download the version without the watermark Table 1. Chemical characterization of cement (C) and metakaolins (J1 and J2).

\begin{tabular}{ccccccccccc}
\hline \multicolumn{10}{c}{ Chemicai (\%) } \\
\hline & $\mathrm{Al}_{2} \mathrm{O}_{3}$ & $\mathrm{SiO}_{2}$ & $\mathrm{Fe}_{2} \mathrm{O}_{3}$ & $\mathrm{CaO}$ & $\mathrm{MgO}$ & $\mathrm{SO}_{3}$ & $\begin{array}{c}\text { Loss } \\
\text { Ignit. }\end{array}$ & $\begin{array}{c}\text { Free } \\
\mathrm{CaO}\end{array}$ & $\begin{array}{c}\text { Insoluble } \\
\text { Residues }\end{array}$ & $\begin{array}{c}\text { Alkali } \\
\text { Content }\end{array}$ \\
\hline $\mathrm{C}$ & 4.24 & 18.48 & 2.63 & 61.02 & 4.33 & 2.76 & 4.99 & 0.78 & 1.10 & 0.66 \\
\hline $\mathrm{J} 1$ & 37.1 & 52.7 & 2.3 & 0.1 & 1.0 & --- & 2.7 & --- & --- & 1.5 \\
\hline $\mathrm{J} 2$ & 39.5 & 47.6 & 5.3 & 0.1 & 0.3 & --- & 4.7 & --- & --- & 0.5 \\
\hline
\end{tabular}

The two metakaolins showed different chemical compositions. J1 has higher $\mathrm{SiO}_{2}$ content and the reddish coloration of metakaolin $\mathrm{J} 2$ is explained by the higher iron oxide content in this material. Regarding fineness, J2 is $30 \%$ finer than J1. Despite these differences, the two metakaolins studied showed very similar pozzolanic activity (modified Chapèlle - NF P18-513: 2012). 
Table 2. Metakaolins' complementary characterization.

\begin{tabular}{|c|c|c|c|c|}
\hline Metakaolin & Aspect/Colour & $\begin{array}{c}\text { Specific gravity } \\
\left(\mathrm{g} / \mathrm{cm}^{3}\right)\end{array}$ & $\begin{array}{c}\text { BET Fineness } \\
\left(\mathrm{m}^{2} / \mathrm{g}\right)\end{array}$ & $\begin{array}{c}\text { Chapèlle } \\
\left(\mathrm{mg} \mathrm{CaOH}_{2} / \mathrm{g}\right)\end{array}$ \\
\hline $\mathrm{J} 1$ & & 2.58 & 22.13 & 1037 \\
\hline $\mathrm{J} 2$ & & 2.60 & 28.71 & 1075 \\
\hline
\end{tabular}

\subsection{Preparation of Specimens and Test Methods}

Three different mortars were produced, one as reference and the other two with $10 \%$ replacement of cement by metakaolin J1 or J2, in mass. The mortars were produced with a 1:2 mixture (binder:sand, in mass), since this is a mix proportion commonly used in the mortar fraction of various concrete mix designs (1:2:3-binder:sand:gravel). The consistency index was maintained in $320 \pm 20 \mathrm{~mm}$ (according to ASTM C230: 2014). After mixing, two mortar specimens were cast, under controlled conditions, in prismatic dimensions of 40x40x160 mm (ASTM C349: 2018). The mortars' composition and identification are shown in Table 3.
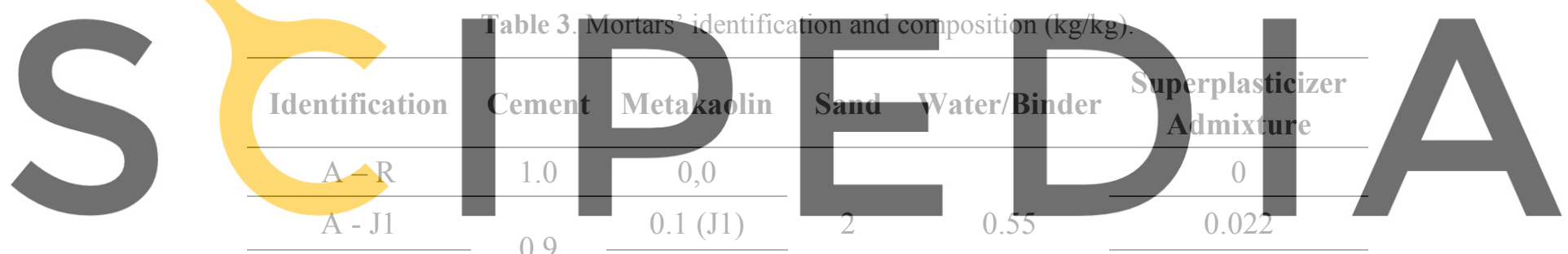

Register for free at https//www.scipedia.com to download the version with 3 out the watermark

After 24 hours of molding, the specimens were demolded and subjected to four different curing conditions: no wet curing and curing by immersion in lime saturated water for 3,9 and 28 days. For the specimens without wet curing, they were packed in PVC plastic after demolding and stored in a laboratory until the tests performing. For those specimens cured for 3 and 9 days, they were air-dried for about two hours (after the curing period) and then packed by means of PVC plastic until they reached the testing age of 28 days, in order to prevent natural carbonation.

At 28 days of age, the accelerated carbonation test ( 7 days) was started. Before the start of carbonation, the specimens were preconditioned with humidity $(70 \pm 5 \%)$ and temperature $\left(20 \pm 1^{\circ} \mathrm{C}\right.$ ) controlled (no $\left.\mathrm{CO}_{2}\right)$, according to standard ISO 1920-12 (2015). It was used one $\mathrm{CO}_{2}$ incubator, model $6034-1$, Caron brand, with temperature of $(20 \pm 1)^{\circ} \mathrm{C}$, relative humidity of $(70 \pm 5) \%$ and $\mathrm{CO}_{2}$ content of $10 \%$. The carbonation depth was measured by spraying the $\mathrm{pH}$ indicators (thymolphthalein and phenolphthalein-based solutions) and using a digital calliper with an accuracy of $0.01 \mathrm{~mm}$, as shown in Figure 1. Each specimen was sliced two times, resulting in a four-sided measurement of 40 x $40 \mathrm{~mm}$, a specimen. In 2 faces the phenolphthalein was applied, and in the other two it was the thymolphthalein. On each side 4 
measures were taken (in the central region on each side), which implies that the mean results of carbonation depth were obtained using 16 individual measures.

The compressive strength test (ASTM C349:2018) was performed with the mortars subjected to wet curing for 28 days.

a)

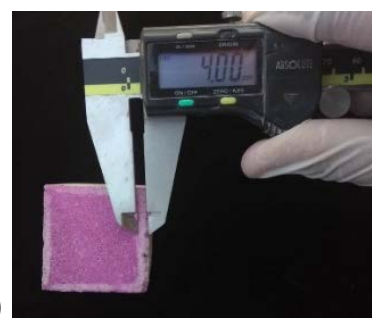

b)

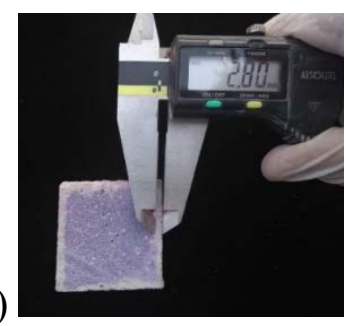

Figure 1. Measurement of carbonated depth using a) phenolphthalein and b) thymolphthalein.

For result analysis, the data was treated with Dixon statistic test (ASTM E178: 2016) in order to remove spurious values, and then analyzed using variances analysis (ANOVA) to identify the study's significant variables. In addition, multiple comparisons of means were performed by the Duncan test.

\section{Results and Discussion}
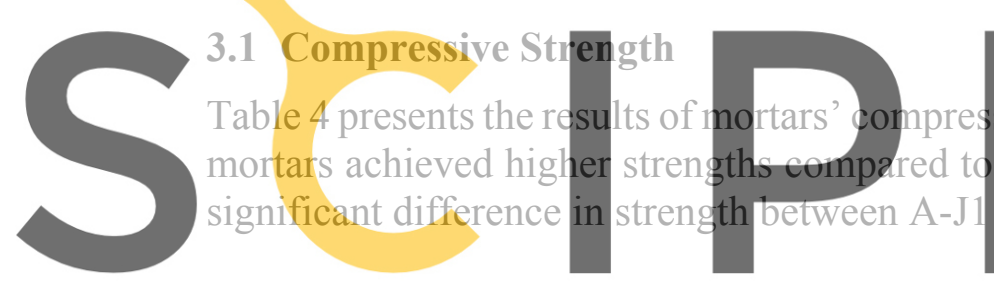

Table 4. Compressive Strength at 28 days of age.

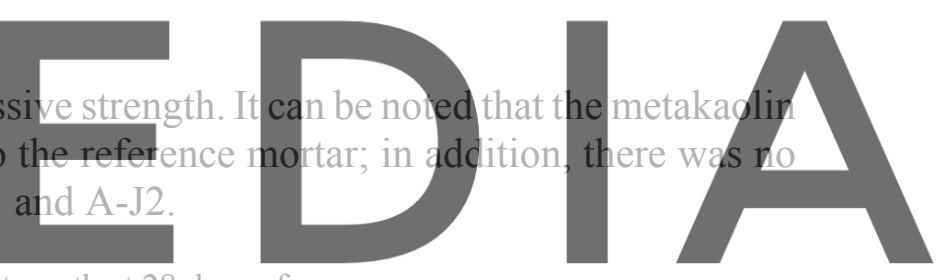

Register for free at https//www.scipedia.com to downkad thelverision without the watermark

\begin{tabular}{c|c|c|c}
\hline Compressive Strength - mean (MPa) & 34 & 43 & 42 \\
\hline Standard Deviation $(\mathrm{MPa})$ & 10.4 & 5.0 & 2.7 \\
\hline
\end{tabular}

\subsection{Carbonation}

The results of mortars' carbonation depth, for different curing situations, are presented in Figure 2. The carbonation depth is reduced with wet curing, showing the importance of performing curing in order to increase the durability of reinforced concrete. Comparing carbonation depths of mortars submitted to wet curing for 28 days and mortars not submitted to wet curing, it is possible to observe a reduction in carbonation up to $70 \%$ for A-R, and $45 \%$ for A-J1 and A-J2.

The increase of wet curing time from 3 to 28 days reflected in a less pronounced depth reduction, about $50 \%, 25 \%$ and $30 \%$ for mortars A-R, A-J1 and A-J2, respectively. It is interesting to note that the type of curing exerts a greater influence on the reference mortar than on the metakaolin mortars (A-J1 and A-J2). It was found that concretes modified with metakaolin without the application of any curing procedure show superior carbonation resistance compared to reference concretes. From the literature, it is known that mineral additions such as blast furnace slag and fly ash require wet curing for a long time to consolidate 
the pozzolanic reactions (Sulapha et al., 2003), and that superpozzolans such as silica fume, nanosilica and metakaolin are generally not sensitive to wet curing (Couto et al., 2003). This was verified in the present work for metakaolin and the main argument on the issue is based on the physical transformation capacity of the cement paste by the action of pozzolan, which reduces porosity and refines pores, thus increasing the volume of micropores capable of retaining water in its capillary structure (Duan et al., 2013). In these cases, it can be said that self-healing occurs due to changes in the material's microstructure.

The analysis of variance - ANOVA (Table 4) confirms the statement that the type of curing exerts a strong influence on the carbonation depth, while type of mortar did not present significant effect on the results of this research.

Table 4. Carbonation depth ANOVA.

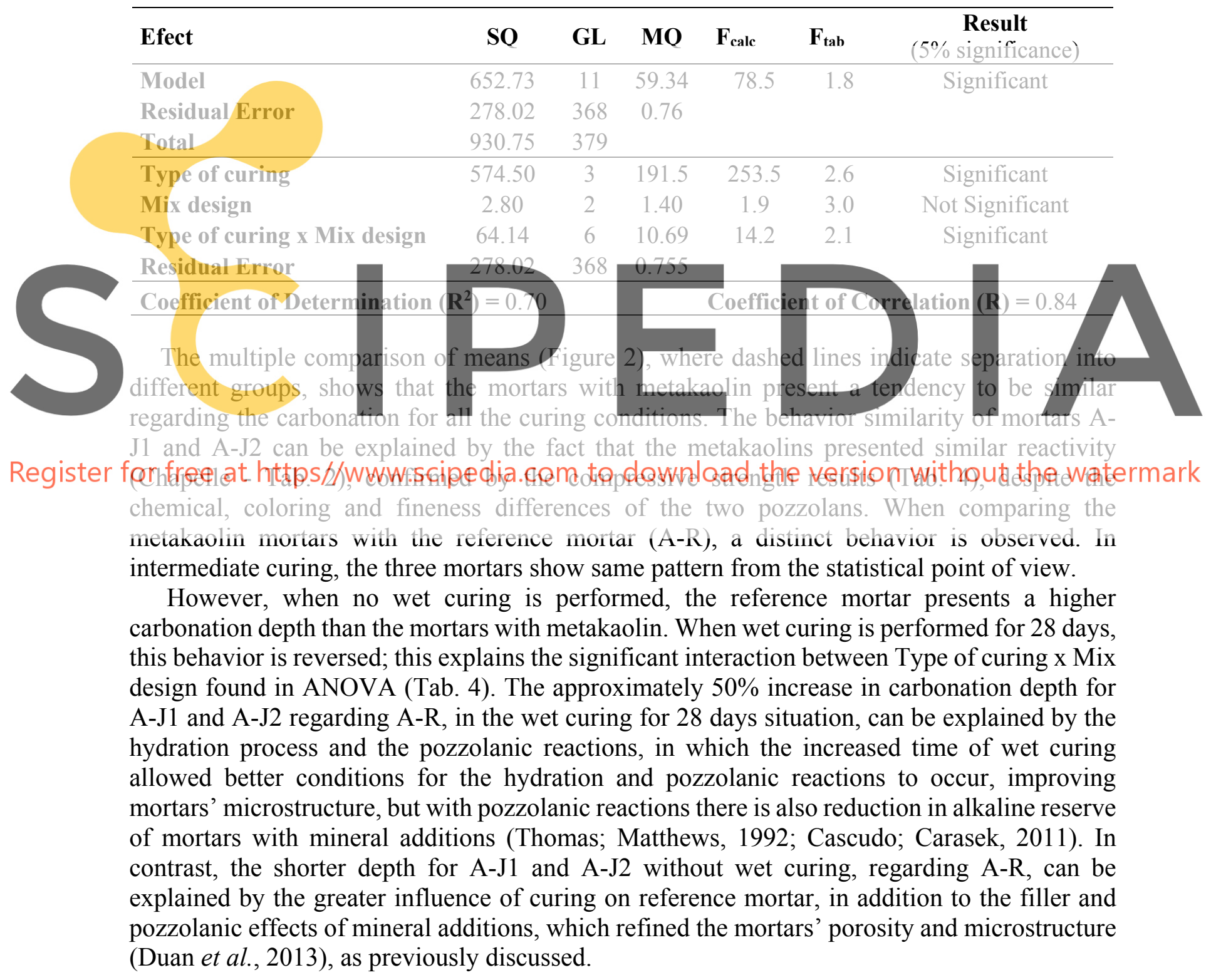




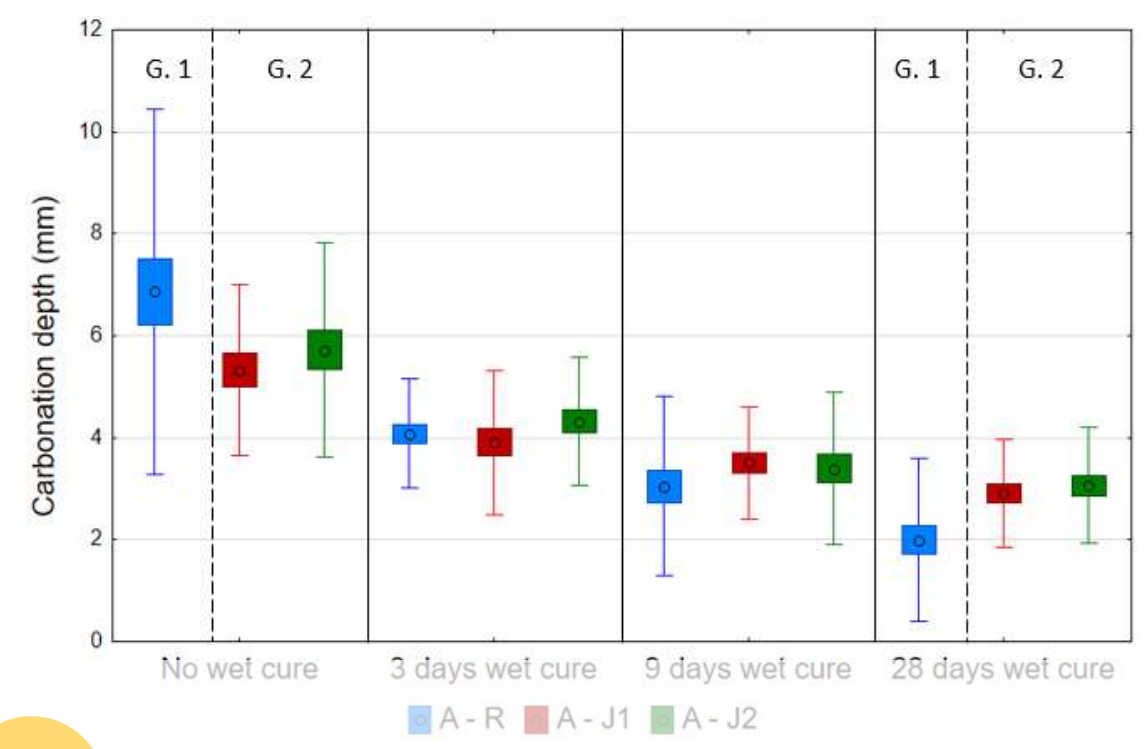

Figure 2. Carbonation depth results analyzed with multiple comparison of means.

\subsection{Relationship Between pH Indicators}

Figure 3 shows the relationship between the carbonated depth measurements made with thymolphthalein and phenolphthalein, and the strong correlation between these two variables $\left(\mathrm{R}^{2}=0.89\right)$. It is noted that, in general, the thymolphthalein indicated greater depths than the phenolphthalein, which can be attributed to the difference between the indicators' pH turning ranges (phenolphthalein from 8.0 to 9.8 and thymolphthalein from 9.3 to 10.5 ). Other author (such as: Kazmierczak; Lindenmeyer, 1996; Yu; Lee; Chung, 2010, Reis; Cannões; Ribeiro, 2016; Revert et al., 2016, Thidl; Gehlen, 2019) have worked with indicators and discussed the relationships between the measurements obtained.

Register for free at https//www.scipedia.com to download the version without the watermark

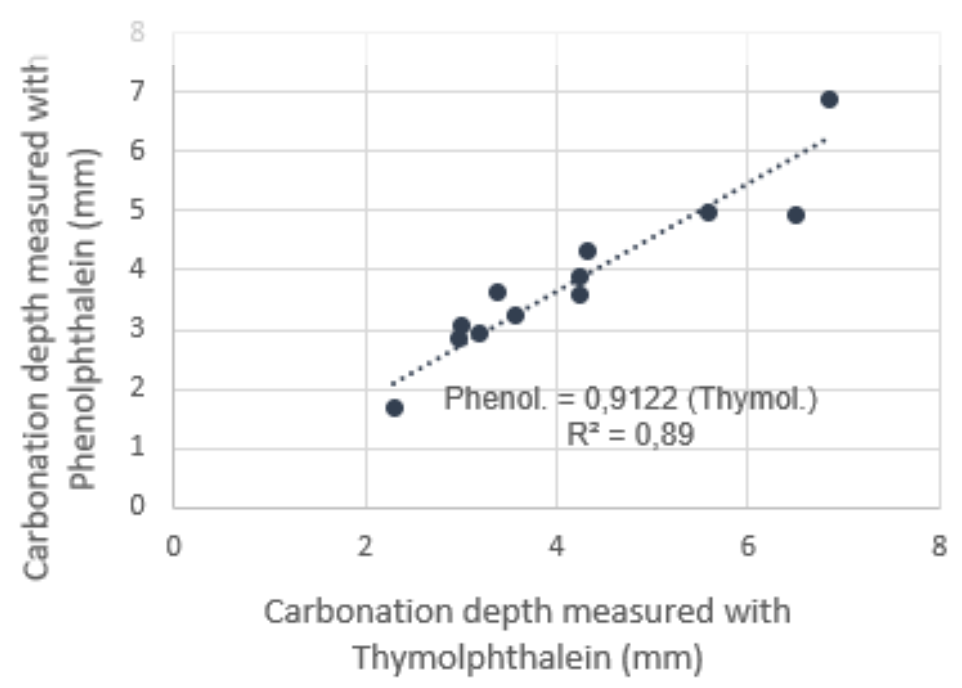

Figure 3. Relationship between carbonated depths with different $\mathrm{pH}$ indicators. 
The equation obtained for this correlation can be highlighted; the carbonated depth readings with phenolphthalein are equivalent to 0.9 times the readings taken with thymolphthalein. An interesting aspect, and perhaps new, was noticed: this relationship between the variables matches the relationship between the two extremes of the $\mathrm{pH}$ ranges nominated by the different $\mathrm{pH}$ indicators $(9.3 / 10.5=0.9$; where 9.3 is the maximum $\mathrm{pH}$ indicated by phenolphthalein and 10.5 is maximum by thymolphthalein).

\section{Conclusions}

Based on the research presented, the following conclusions can be drawn:

Despite of the chemical, coloring and fineness differences of both metakaolins studied, there were no statistically significant differences regarding the carbonated depths of the mortars prepared with them. These metakaolins had similar pozzolanic activity (measured by the Chapèlle method), showing that this characteristic is very relevant to explain the carbonation of mortars with metakaolin.

The curing condition had a strong influence on carbonated depths of mortars. This depth is reduced with wet curing and with the increased time of immersion in water, showing the importance of wet curing for increasing the durability of reinforced concrete. However, metakaolin mortars are less affected by wet curing when compared to the non-pozzolan mortars (reference cementitious mortars). This is certainly due to a self-healing action exerted by a retention capacity.

As for the carbonate

thymolphthalein based variables $\left(\mathrm{R}^{2}=0.89\right)$. times the measured reading
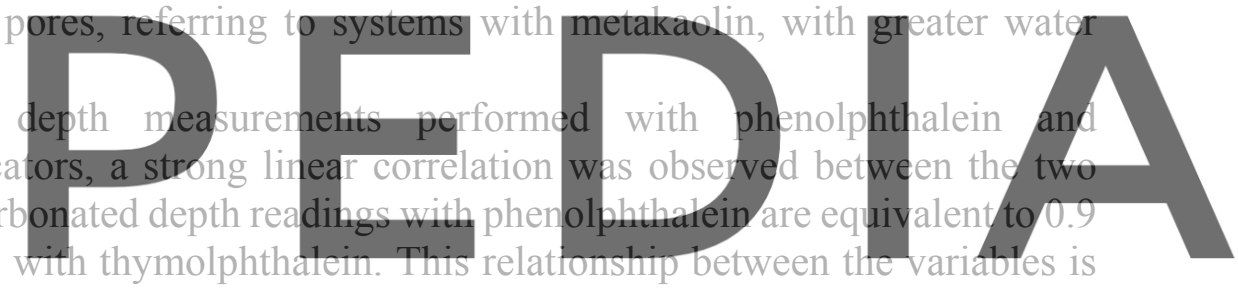
exactly the relationship between the two extremes of the indicators' $\mathrm{pH}$ turning ranges

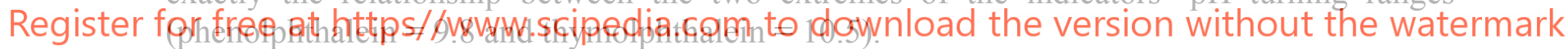

Acknowledgements

The authors would like to thank: Coordenação de Aperfeiçoamento de Pessoal de Nível Superior (CAPES) Brazil, Eletrobras FURNAS and the technicians of LABITECC-UFG - Brazil.

\section{ORCID}

Helena Carasek: https://orcid.org/0000-0002-1170-0980

Mônica E. Jungblut: https://orcid.org/0000-0003-2111-0666

Paulo M. Passos: https://orcid.org/0000-0002-2934-9279

Oswaldo Cascudo: https://orcid.org/0000-0003-1879-6396

\section{References}

Cascudo, O. and Carasek, H. (2011). Ação da Carbonatação no Concreto. In G. C. ISAIA (Ed.), Concreto: Ciênica e Tecnologia. São Paulo, SP: IBRACON, 849-885.

Castro, A., Ferreira, R., Lopes, A., Couto, A. P., Braun, V., Carasek, H. and Cascudo, O. (2007). Influência das adições minerais na durabilidade do concreto. In IV Congresso de Inovação Tecnológica em Energia Elétrica. Araxá: ANEEL, 1-8.

Couto, A. B. P. ; Cascudo, O. ; Carasek, H. and Lopes, A. N. M. (2003). Influência das condições de cura na 
durabilidade de diferentes concretos. In 45. Congresso Brasileiro do Concreto, Vitória. Anais de CD-ROM. São Paulo: IBRACON, 1, 1-15.

Duan, P., Shui, Z., Chen, W. and Shen, C. (2012). Influence of metakaolin on pore structure-related properties and thermodynamic stability of hydrate phases of concrete in seawater environment Construction and Building Materials, 36, 947-953. doi: 10.1016/j.conbuildmat.2012.06.073

Duan, P., Shui, Z., Chen, W. and Shen, C. (2013). Enhancing microstructure and durability of concrete from ground granulated blast furnace slag and metakaolin as cement replacement materials Journal of materials Research and Technology, 2(1), 52-59. doi: 10.1016/j.jmrt.2013.03.010

Hossain, M. M., Karim, M. R., Hasan, M., Hossain, M. K. and Zain, M. F. M. (2016). Durability of mortar and concrete made up of pozzolans as a partial replacement of cement: A review Construction and Building Materials, 116, 128-140. doi: 10.1016/j.conbuildmat.2016.04.147

Kazmierczak, C. S. and Lindenmeyer, Z. (1996). Comparação entre metodologias utilizadas para a determinação da profundidade de carbonatação em argamassas. In Proceedings of the International Congress on Highperformance and Quality of Concrete Structures, Florianópolis, Brazil, 402-413.

Lim, S. and Mondal, P. (2015). Effects of incorporating nanosilica on carbonation of cement paste Journal of Materials Science, 50(10), 3531-3540. doi: 10.1007/s10853-015-8910-7

Meddah, M. S., Ismail, M. A., El-Gamal, S. and Fitriani, H. (2018). Performances evaluation of binary concrete designed with silica fume and metakaolin Construction and Building Materials, 166, 400-412. doi: 10.1016/j.conbuildmat.2018.01.138

Papadakis, V. G. (2000). Effect of supplementary cementing materials on concrete resistance against carbonation and chloride ingress Cement and concrete research, 30, 291-299. doi: 10.1016/S0008-8846(99)00249-5

Reis, R., Camões, A. and Ribeiro, M. (2016). Using Thymolphthalein for Accelerated Carbonation Testing of High Volume Fly Ash Cementitious Blends. In Service Life and Durability of Reinforced Concrete Structure, Marnela-Vallée, France, 17-30.

Revert, A., De Weerdt, K., Hornbostel, M. and Geiker, M. (2016), Carbonation Characterization of Mortar with Portland Cement and Fly Ash, $1 / 2016,60-76$

Rossignolo, J. A. and Oliveira, I. L. e Tecnologia, 3(2), 177-187.

Sulapha, P., Wong, S. F Mineral Admixtures Journal
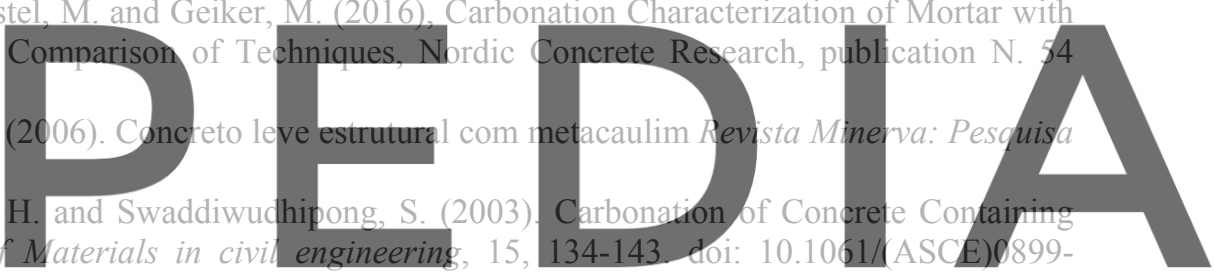
1561(2003)15:2(134)

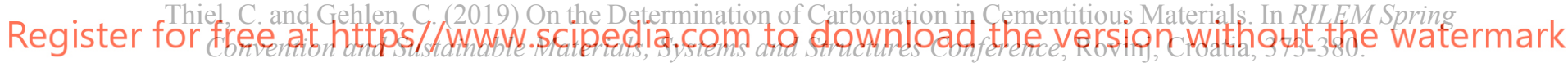

Thomas, M. D. A. and Matthews, J. D. (1992). Carbonation of fly ash concrete Magazine of Concrete Research, 44(160), 217-228. doi: 10.1680/macr.1992.44.160.217

Yu, M., Lee, J and Chung, C. (2010), The Application of Various Indicators for the Estimation of Carbonation and $\mathrm{pH}$ of Cement Based Materials, Journal of Testing and Evaluation 38, no. 5: 534-540 